\title{
Lex specialis derogat lex generali, of: lex generali derogat lex specialis
}

\author{
Prof. Mr. Drs. H. Beckman
}

\begin{abstract}
Een heschouwing naar aanleiding van Hoogendoorns bijdrage: 'Derogatie: afu'ijking van specifieke wettelijke bepalingen ten behoeve van het inzicht.'
\end{abstract}

\section{$1 \quad$ Inleiding}

Het Nederlandse jaarrekeningenrecht vormt een onderdeel van ons privaatrecht. Daaruit volgt dat het jaarrekeningenrecht nimmer geïsoleerd kan worden beschouwd. Algemene rechtsbeginselen, rechtsovertuigingen en maatschappelijke opvattingen spelen hierbij een rol. Het jaarrekeningenrecht kan ook niet geïnterpreteerd worden alsof er geen ander recht bestaat. In het bijzonder is voor het jaarrekeningenrecht van belang het vermogensrecht en het vennootschapsrecht (waartoe het jaarrekeningenrecht behoort).

De rechtspersoon staat in talloze betrekkingen tot anderen. Hij bestiert een onderneming. Dit leidt tot commerciële en zakelijke betrekkingen. Kenmerkend daarbinnen zijn de vermogensrechtelijke betrekkingen die door handelingen ontstaan. Er vinden aan- en verkopen plaats, worden investeringen en desinvesteringen gepleegd, er wordt gewerkt met mensen, er wordt geleend of geëmitteerd etc. Er kan ook onzorgvuldig worden gehandeld door of tegenover de rechtspersoon, hetgeen tot schadeclaims aanleiding kan geven, er gelden wettelijke verplichtingen etc. In de jaarrekening komen de (financiële) gevolgen van al deze (rechts)handelingen (feiten, transacties etc.). Zij

Prof. Mr. Drs. H. Beckman is advocaat te Amsterdam, partner Stibbe Simont Monahan Duhot, alsmede hoogleraar te Rotterdam. brengt tot uitdrukking de uitkomsten van het gevoerde beleid en de weerslag daarvan op de financiële positie, het vermogen en het resultaat. Door middel hiervan legt (het bestuur van) de rechtspersoon verantwoording af en informeert de rechtspersoon derden die als zodanig buiten de rechtspersoon staan, zoals zij die zaken met de rechtspersoon hebben gedaan of overwegen te doen, degenen die beleggen in waardepapieren van de rechtspersoon of overwegen zulks te doen.

De verantwoording en de informatieverschaffing dienen naar behoren te geschieden. Dit geldt, ook al zou er geen enkele bepaling van jaarrekeningenrecht bestaan. Degene die zich verantwoordt, dient rekening en verantwoording af te leggen conform hetgeen heeft plaatsgevonden en dient erop verdacht te zijn dat derden handelingen op basis van de afgelegde verantwoording kunnen ondernemen. De grondslag voor de (financiële) verantwoording vormt de civielrechtelijke administratieplicht. Deze plicht is voor een ieder die in Nederland een bedrijf of beroep uitoefent, verankerd in art. 3:15A BW en tevens voor (privatrechtelijke) rechtspersonen, ongeacht de plaats van werkzaamheden. in art. 2:10 BW.

De zojuist genoemde bepalingen leggen op een ondernemer (degene die een beroep of bedrijf uitoefent) en op het bestuur van de rechtspersoon de plicht naar de eisen van de onderneming respectievelijk aard van de werkzaamheden een zodanige administratie te voeren dat daaruit te allen tijde de rechten en verplichtingen kunnen worden gekend en dat daaruit jaarlijks een balans en een staat van baten en lasten kunnen worden opgesteld. De verwijzing naar de eisen van de onderneming (beroep, bedrijf) en aard van de werkzaamheden vormt hierbij een leidraad voor het handelen. Een specifieke normering is hierbij niet gegeven. 
Niettemin mag worden aangenomen dat algemeen aanvalarde beginselen van verantwoording ( het zgn. goed koopnansgebruik), rekening houdende mee bedrijfstakgebruiken, maatgevend zijn.

Op zichzell beschouwd stiat het degene die verantwoording moel afleggen en degene aan wie verantwoording moet worden afgelegd, vrij afspraken te maken over de grondslagen die bij de verantwoording gehanteerd zullen worden. Deze afspraken zullen ler voorkoming van misverstand schriftelijk worden vastgelegd: voor de duidelijkheid zullen zij veelal dian de balans en de stalat van baten en lasten worden toegevoegd ("1oelichting"). Zolang sprake is van een besloten relatie. zal zulks geen bezwaar oproepen. Dit word1 anders zodra de ondernemer/rechtspersoon een beroep doet op de kapilaalmarkt en/of werkzalamheden verricht walarbij het publiek vertrouwen in hel geding is. Dit verklaarl dat in 1929 voor publikatieplichtige NV's (beperkte) inrichtingseisen voor de jalarrekening - meer in het bijzonder voor de balans - in de wet werden opgenomen. De inrichtingseisen gingen na invoering van de Wet op de jaarrekening van ondernemingen de gehele jaarrekening betreffen. met een beperkte uitbreiding van de kring van publikalieplichtige ondernemingen. Hierbij mag een zekere unilormering van wijze van verantwoording en informatieverschalling worden verwacht. Meer in het bijzonder geldt zulks voor beursgenoteerde ondernemingen en voor banken en verzekeralars. Hierbij is onder meer an het vergelijkbatarheidsmotiel te denken.

\section{Communautaire ontwikkelingen}

Naast nationale ontwikkelingen waren er ook communautaire ontwikkelingen. Uit oogpunt van derdenbescherming ontstond de behoefte aan publikatieplicht: een afgeleid gevolg daarvan was de behoefte aan geharmoniseerde vershaggeving binnen de Europese Gemeenschappen. Andere overwegingen betroffen onder meer hel creëren vall gelijk walardige concurrentieverhoudingen en het voorkomen valn 'accounting shopping". Relevante richtlijnen zijn hierbij met name de Vierde EEG-richtlijn ( 1978) en Zevende EEG-richtlijn (1983). In een alantal gevallen zijn voor dezelfde onderwerpen in deze richtlijnen opties opgenomen hetzij naar keuze van de lidstaten hetzij naal keuze van de aan deze richtlijnen onderworpen rechispersonen. Deze opties zijn vanuil com- munautair oogpunt als gelijk waardig te beschouwen. Hel voldoen aun de richtlijnvoorschriften leidt ertoe dat de jaarrekening een getrouw beekt geeft van de financiële positie. het vermogen en het resultaat van de rechtspersoon (enkelvoudige jairrekening) respectievelijk van de geconsolideerde eenheid (geconsolideerde jaarrekening). De richtlijn-voorschriften betreffen zowel jaarrekeningmodellen als algemene walarderingsbeginselen en walarderingsregels.

Binnen de modellen zijn verdergaande uitsplitsingen mogelijk dan de in de richtlijnen opgenomen modellen. Indeling, omschrijving en terminologie van posten binnen de rubrieken van deze modellen moeten worden aangepast wanneer zulks vereist is wegens de bijzondere alard van de onderneming: een lidstatat kan dit ook voorschrijven indien een onderneming deel uilmaakt van een bepaalde economische sector. Van de modellen moet voor beleggingsmatschappijen en participaticmaatschappijen worden afgeweken. indien een lidstat speciale modellen heeft uitgevaardigd ${ }^{2}$. Daartoe is een lidstiat bevoegd mits deze modellen een beeld geven dat gelijkwalardig is aan het in de richtilijnen bedoelde beeld.

Omtrent de algemene wiarderingsbeginselen bepaalt de richtlijn dal afwijking in uirzonderingsgevallen is toegestalan. mits vermelding in de toelichting platsvindt, naar behoren gemotiveerd met opgaal van de invloed op het vermogen en het resultaal (art. 31 lid 2 Vierde EEG-richtlijn). Voorts kan een lidstaat aan beleggingsmaatschappijen de grondslag marktwarde toestaan en, bij toepassing van de historische kostengrondslag. voor tot de financiële valste aletiva behorende effecten dat watadecorrecties rechtstreeks in het cigen vermogen worden verwerkt.

Het voorgiande laat zien dat de richtlijn zelf voorziet in de regels die gelden voor af wijking van modellen (beleggingsmaatschappijen, participatiemaatschappijen), voor af wijkingen binnen modellen (bijzondere aard onderneming, deel uilmaken bepaalde economische sector). bij afwijking van de algemene walarderingsbeginselen (in uilzonderingsgevallen ) en voor afwijkende waarderingsgrondslagen (beleggingsmaatschappijen). Deze regels maken deel uil van het stelsel valn bepalingen dat constituerend is voor het in de richtlijn bedoelde getrouwe beeld van de financiële positie. het vermogen en het resultaal. 
Met inachtneming van het opgemerkte betekent het voldoen aan de richtlijnbepalingen dat een getrouw beeld van de financiële positie, het vermogen en het resultaat wordt gegeven. Daar waar afwijking geboden is, voorzien de richtlijnen erin, of moet een lidstaat erin voorzien dan wel kan een lidstaat een binnen de richtlijnen geoorloofde afwijkende regeling toestaan. Denkbaar zou evenwel zijn dat desondanks het voldoen aan deze bepalingen onvoldoende is om het in de richtlijn bedoelde beeld te geven. In dat geval schrijft de richtlijn voor dat aanvullende informatie in de toelichting moet worden opgenomen (art. 2 lid 4 Vierde EEG-richtlijn). Men zou deze bepaling kunnen typeren als een soort 'sluitstukbepaling'. Het is nu eenmaal niet mogelijk alles te regelen: aldus kunnen bijzondere omstandigheden van een onderneming ertoe leiden dat in de toelichting aanvullende informatie moet worden opgenomen.

Daarnaast is er een voorschrift waarin staat dat als in uitzonderingsgevallen blijkt dat toepassing van een bepaling van de richtlijn-verplichting een getrouw beeld van de financiële positie, het vermogen en het resultaat te geven, van die bepaling moet worden afgeweken opdat dit getrouwe beeld wèl wordt gegeven (art. 2 lid 5 Vierde EEG-richtlijn). De vraag die opkomt, is wat de betekenis van dit voorschrift is. Deze betekenis is er niet voor de rubricering binnen de modellen (daarvoor geldt reeds een afzonderlijk voorschrift), hooguit wèl voor beleggingsmaatschappijen en participatiemaatschappijen indien een lidstaat geen afzonderlijke modellen heeft voorgeschreven. De betekenis ontbreekt ook voor een afwijking van de algemene waarderingsbeginselen, omdat de richtlijn die afwijking in uitzonderingsgevallen reeds toestaat; wanneer deze uitzonderingsgevallen optreden, wordt beheerst door de verplichting een getrouw beeld te geven, m.a.w. of sprake is van een uitzonderingsgeval moet beoordeeld worden in het licht van de getrouwheidseis. De betekenis ontbreekt ook voor beleggingsmaatschappijen: waardecorrecties van effecten mogen alleen dan rechtstreeks in het eigen vermogen worden verwerkt indien - bij de grondslag historische kostprijs - een lidstaat zulks toestaat; waardering tegen marktwaarde is ook alleen geoorloofd indien een lidstaat zulks toestaat.
Wat is dan wèl de betekenis? De betekenis kan er hooguit zijn voor de toepassing van de waarderingsvoorschriften. De uitleg moet dan zijn dat afwijking geboden is, wanneer in de gegeven omstandigheden van het geval de toepassing van een waarderingsvoorschrift van de richtlijn onaanvaardbaar zou zijn gelet op het beoogde doel van de jaarrekening, te weten het verschaffen van een getrouw beeld van de financiële positie, het vermogen en het resultaat. Daaruit volgt dat nimmer een algemene regel omtrent afwijking van de bepalingen van de richtlijn kan worden geformuleerd. Het totaalinzicht staat voorop. Als de toepassing van een bepaling naar het oordeel van de opsteller van de jaarrekening niet juist is, ontstaat geen vrijbrief tot afwijking. Slechts indien in essentie 'een getrouw beeld ' wordt aangetast, komt afwijking aan de orde; deze is dan verplicht, met vermelding van de invloed op het vermogen (activa, passiva, eigen vermogen) en het resultaat. Is in essentie het in de richtlijn bedoelde beeld niet aangetast, dan past geen afwijking. Hooguit kan sprake zijn van het verstrekken van aanvullende inlichtingen.

\section{Titel 9: onderdeel van Boek 2 BW}

De uitwerking van de Vierde en Zevende EEG-richtlijn in de Nederlandse wet is opgenomen in Boek 2 BW (daarvan thans: Titel 9). De Nederlandse wetgever is verplicht deze richtlijnen zo goed mogelijk te verwerken. Daarbij mogen - binnen de grenzen van de richtlijnen strengere eisen worden gesteld. De plaatsing in Boek 2 BW betekent dat Titel 1 Boek 2 BW van toepassing is. Deze titel bevat algemene bepalingen van het rechtspersonenrecht. De slotbepaling van deze titel (art. 2:25 BW) luidt: 'Van de bepalingen van dit boek kan slechts worden afgeweken, voor zover dat uit de wet blijkt'. Dit voorschrift laat zien dat de bepalingen van Boek $2 \mathrm{dwingend}$ recht zijn. Afwijkingen zijn alleen dan geoorloofd voor zover de wet zulks laat blijken. Die afwijking kan blijken uit Boek 2 BW zelf, maar ook uit afzonderlijke wetten. Een bijzondere regel kan derhalve een afwijking bewerkstelligen.

Titel 9, jaarrekening en jaarverslag, behoort tot Boek $2 \mathrm{BW}$, zodat het bepaalde in Titel 9 $\mathrm{dwingend}$ recht is. Van de algemene en bijzondere voorschriften van deze titel kan daarom 
slechts worden afgeweken, voor zover dat uit de wet blijkt, m.a.w. de diverse in Titel 9 genoemde afwijkingsmogelijkheden zijn bijzondere regels die in uitzonderingsgevallen of in het gegeven geval jaarrekeningregels van dwingendrechtelijke aard opzij kunnen zetten. Zonder bijzondere regels zijn afwijkingen niet geoorloofd. Het algemene voorschrift dat de jaarrekening een getrouw beeld moet geven van de financiële positie, het vermogen en het resultaat ${ }^{3}$, is een evident voorbeeld van een bepaling waarvan niet mag worden afgeweken. De bijzondere voorschriften van Titel 9 bevatten ook evidente voorbeelden van bepalingen waarvan niet mag worden afgeweken, zoals de bepalingen waarin is voorgeschreven dat afschrijvingen en waardeverminderingen onafhankelijk van het resultaat moeten worden berekend. (artt 2:386 lid 1 en 387 lid $1 \mathrm{BW}$ ).

De bijzondere voorschriften van Titel 9 bevatten ook bepalingen die kunnen nopen tot het verschaffen van aanvullende inlichtingen, zoals het bepaalde in art. 2:375 lid 3 BW (vermelding van positieve en/of negatieve hypotheekclausules bij aangegane verplichtingen, voor zover noodzakelijk voor het inzicht). Bijzondere voorschriften kunnen ook beperkingen in de informatieverschaffing toestaan. Als voorbeelden noem ik het niet toelichten van buitengewone baten en lasten indien zij van ondergeschikte betekenis zijn (art. 2:377 lid 7 BW), het niet-vermelden van informatie over deelnemingen en omzetsegmentatie in geval van ontheffing door de minister (artt 2:379/ 414 lid 4 BW resp. art 2:380 lid 5 BW), het niet vermelden van gegevens over de moedermaatschappij, mits de moedermaatschappij wettig bevrijd is van de plicht om informatie over die groepsmaatstaven te vermelden (art. 2:379 lid 3 BW). Ook kan een bijzonder voorschrift een algemeen beginsel opzij zetten. Een duidelijk voorbeeld is art. 2:414 lid 3, eerste volzin BW: de gegevens over een niet-geconsolideerde deelneming in een dochtermaatschappij mogen in de toelichting van de geconsolideerde jaarrekening niet onvermeld blijven, indien vermelding dienstig is voor het inzicht, ook al is de deelneming van te verwaarlozen betekenis.

De bijzondere voorschriften van Titel 9 bevatten ook bepalingen die de bevoegdheid geven van waarderingsgrondslagen af te wijken, maar wel geclausuleerd. Voor de enkelvoudige en geconsolideerde jaarrekening gaat het om art. 2:384 lid $6 \mathrm{BW}$. Deze bepaling vormt een onderdeel van hetgeen in art. 31 lid 2 Vierde Richtlijn is beoogd (in uitzonderingsgevallen mag van een algemeen waarderingsbeginsel worden afgeweken). De Nederlandse wetgever spreekt over afwijking wegens gegronde redenen. Het is dus een bijzonder voorschrift dat de afwijkingsbevoegdheid van een bestendige gedragslijn in de waarderingsgrondslagen regelt. Voorbeelden van een gegronde reden kunnen zijn: verandering in wetgeving, wijziging in de opvatting omtrent de maatschappelijke aanvaardbaarheid, aanpassing grondslagen aan die van de moeder. Daarbij blijft gelden het bijzondere voorschrift dat in art. 2:384 lid $1 \mathrm{BW}$ is opgenomen: bij de keuze moet de rechtspersoon zich laten leiden door art. 2:362 leden 1-4. Het bijzondere voorschrift wijst derhalve de gedragsnorm aan.

Omtrent de verhouding tussen de grondslagen van de enkelvoudige jaarrekening en die van de geconsolideerde jaarrekening is mede van belang het bepaalde in art. 2:410 lid $3 \mathrm{BW}$. Wegens gegronde redenen mogen in de geconsolideerde jaarrekening andere grondslagen dan in de enkelvoudige jaarrekening worden gehanteerd. Dit vloeit dus voort uit een bijzonder voorschrift. De gedragsnorm daarbij volgt via art. 2:384 lid $1 \mathrm{BW}$ uit art. 2:362 leden 1-4 BW.

In de geconsolideerde jaarrekening is proportionele consolidatie voor joint ventures geoorloofd mits hiermee aan het wettelijk inzicht vereiste wordt voldaan (art. 2:409 BW). Het is derhalve een bijzonder voorschrift dat de gedragsnorm van art. 2:362 lid 1 (via art. 2:405 lid 2 BW) aanwijst.

Aldus wordt duidelijk dat de bijzondere voorschriften, met inachtneming van de daarin specifieke verwijzingen leiden tot een getrouw beeld van de financiële positie, het vermogen en het resultaat van de rechtspersoon c.q. groep(sdeel). Bij de toepassing van de bijzondere voorschriften op posten en afzonderlijke vermeldingen speelt de eis van een getrouw beeld in diverse bijzondere voorschriften een rol hetzij door aanvulling of afwijking te verlangen.

Daarnaast bevatten de algemene voorschriften van Titel 9 ook bijzondere bepalingen die tot aanvullende informatie (art. 2:362 lid 4, eerste volzin $\mathrm{BW}$ ) of afwijking (art. 2:362 lid 4, tweede 
volzin $\mathrm{BW}$ ) kunnen leiden. Deze bijzondere bepalingen zijn dwingendrechtelijk en hebben betrekking op het totaal inzicht dat door middel van de jaarrekening moet worden gegeven.

Alvorens daarop in te gaan, veroorloof ik mij een uitstapje naar Titel I van Boek 2 BW. In art. 2:8 BW van deze titel komen bepalingen omtrent redelijkheid en billijkheid ('de objectieve goede trouw') voor. Ik verwijs ook naar het vermogensrecht: ' $\mathrm{Bij}$ de vaststelling van wat redelijkheid en billijkheid eisen, moet rekening worden gehouden met algemeen erkende rechtsbeginselen, met de in Nederland levende rechtsovertuigingen en met de maatschappelijke en persoonlijke belangen, die bij het gegeven geval zijn betrokken (art. 3:12 BW). Met art. 2:8 BW vergelijkbare bepalingen treft men onder meer aan in art. 6:2, 248 en $258 \mathrm{BW}$. Zonder in te veel details te treden kan men grosso modo stellen:

- partijen dienen zich tegenover elkaar te gedragen naar de eisen van redelijkheid en billijkheid (binnen de rechtspersoon: de rechtspersoon en degenen die daarbij betrokken zijn);

- een tussen hen krachtens de wet, gewoonte, rechtshandeling (statuten, reglementen, besluit) geldende regel is niet van toepassing, voor zover die in de gegeven omstandigheden naar maatstaven van redelijkheid en billijkheid onaanvaardbaar zou zijn.

Het eerste kan men aanduiden met de aanvullende werking van de (objectieve) goede trouw, het tweede met de beperkende werking van de (objectieve) goede trouw.

Een parallel lijkt te trekken met het jaarrekeningenrecht van Tite1 9. De hoofdregel is dat een getrouw beeld van de financiële positie, het vermogen en het resultaat moet worden gegeven. Daarbij geldt:

- om tot het getrouwe beeld te komen, kunnen aanvullende inlichtingen vereist zijn (eisen van redelijkheid en billijkheid kunnen ertoe leiden dat een verslaggever aan gebruikers meer informatie verschaft);

in de gegeven omstandigheden kan de toepassing van een regel van jaarrekeningenrecht onaanvaardbaar zijn gelet om het vereiste getrouwe beeld (eisen van redelijkheid en billijkheid kunnen ertoe leiden dat een verslaggever van de toepassing van een specifieke bepaling van jaarrekeningenrecht moet afzien).

Het eerste kan men aanduiden met de aanvullende werking van het getrouwe beeld, het tweede met de beperkende werking van het getrouwe beeld. De eis van een getrouw beeld kan de toepassing van een dwingendrechtelijke regel in de gegeven omstandigheden van het geval beperken. $\mathrm{Zij}$ leidt tot een afwijking, vandaar dat ook wel wordt gesproken over de derogerende werking van het getrouwe beeld.

\section{Tussenconclusie}

Het voorgaande laat zich als volgt samenvatten. Titel 9 Boek $2 \mathrm{BW}$ is dwingend recht (zie art. 2:25 BW). Binnen Titel 9 wordt onderscheid gemaakt tussen algemene voorschriften en bijzondere voorschriften. De bijzondere voorschriften bevatten voor bepaalde waarderingsgrondslagen en voor afzonderlijke posten dwingendrechtelijke regels tot afwijking en/of aanvullende informatie. Of deze afwijking en/of aanvullende informatie vereist is, kan voortvloeien uit de eis van een getrouw beeld.

Als aldus de jaarrekening is samengesteld, is er nog een overall-toets: is het ontstane beeld in de gegeven omstandigheden van het geval getrouw? Zo niet, dan zijn afzonderlijke inlichtingen vereist teneinde een getrouw beeld te geven (art. 2:362 lid 4 , tweede volzin BW) of indien zulks desondanks niet wordt bereikt, is afwijking geboden (art. 2:362 lid 4, eerste volzin BW). Ik noemde reeds dat het hierbij hoofdzakelijk kan gaan om de toepassing van waarderingsvoorschriften. Daarbij - zo moet voor ogen worden gehouden - kan het alleen gaan om het bijzondere geval: de bijzondere omstandigheden waarin een bepaalde rechtspersoon verkeert, zijn daarbij doorslaggevend. Dit laat zich niet door algemene regels ondervangen.

Mijn tussenconclusie maakt duidelijk dat de stelling van Hoogendoorn, dat anders dan in de overige delen van het recht, in het jaarrekeningenrecht de algemene regel prevaleert boven de bijzondere regel, niet juist is. Aanvullende en beperkende werking zijn begrippen die hedentendage geworteld zijn in ons vennootschaps- en vermogensrecht. Het jaarrekeningenrecht is daarbinnen geen uitzondering. ${ }^{4}$

\section{Argumenten voor en tegen derogatie}

Hoogendoorn bespreekt een aantal argumenten pro en contra derogatie. Met derogatie doelt de auteur op art. 2:362 lid 4, tweede volzin BW. 
Mijn beschouwing maakt duidelijk dat onderscheid behoort te worden gemaakt tussen:

- bijzondere voorschriften van Titel 9 die tot afwijking kunnen nopen: en

- bijzondere bepalingen van de algemene voorschriften die tot afwijking kunnen nopen.

Een duidelijk voorbeeld van de eerste categorie wordt gevormd door de bepaling die wegens gegronde redenen afwijking toestaat van het beginsel van de bestendige gedragslijn in de gehanteerde grondslagen. Een ander voorbeeld is het wegens gegronde reden hanteren van andere grondslagen in de geconsolideerde jaarrekening. Deze afwijkingen, die niets van doen hebben met de door Hoogendoorn bedoelde derogatie, zijn uitvloeisel van de bijzondere voorschriften.

Hetzelfde geldt voor de keuze van de grondslagen; het bijzondere voorschrift wijst als gedragsnorm art. 2:362 leden 1-4 aan.

De tweede categorie is pas aan de orde als de jaarrekening met inachtneming van de bijzondere voorschriften is samengesteld en desondanks toch nog geen getrouw beeld geeft. Dit kan bij een goede toepassing van de bijzondere voorschriften slechts de uitzondering zijn, ongeacht of het nu om de enkelvoudige dan wel om de geconsolideerde jaarrekening gaat. Het pleidooi van Hoogendoorn dat derogatie een absoluut vereiste is, leidt ertoe dat de jaarrekening nog moeilijker interpreteerbaar wordt dan nu al het geval is, en als communicatie-instrument steeds minder serieus moet worden genomen. Ik zal hierna beknopt op de argumentatie van Hoogendoorn ingaan.

Hoogendoorn heeft het over de bedrijfseconomische functie van de jaarrekening indien hij het heeft over derogatie op basis van het algemene inzichtvereiste. Dit is niet juist. Het gaat hierbij om rechtsnormen die dwingendrechtelijk de eis van een getrouw beeld stellen. Deze eis dient de verantwoordingsfunctie (rekenschap en verantwoording jegens het bevoegde orgaan), de grondslag om tot een adequate winstverdeling te komen (winstinhouding versus winstuitkering) en de informatiefunctie (aandeelhouders. beleggers, crediteuren etc.) Niet aan de orde is een tegenstelling tussen 'bedrijfseconomisch' en 'juridisch'.

Uit het pleidooi van Hoogendoorn volgt ook niet een noodzakelijk onderscheid tussen enkelvoudige en geconsolideerde jaarrekening en evenmin dat derogatie alleen mogelijk moet zijn in de geconsolideerde jaarrekening. Pleidooien voor een onderscheid tussen enkelvoudige en geconsolideerde jaarrekening vinden hun oorsprong in de Franse wetgeving. Gelet op het 'unicité'-beginsel tussen de jaarrekening en de fiscale stukken in Frankrijk, zijn bepaalde grondslagen aldaar in de enkelvoudige jaarrekening niet mogelijk (bijv. activering financiële lease, latenties). Dit speelt in Nederland niet. Bovendien is het in Nederland ook geoorloofd andere grondslagen in de geconsolideerde jaarrekening te gebruiken, mits er gegronde redenen zijn (het bijzondere voorschrift van art. 2:410 lid $3 \mathrm{BW}$ ). Wat Hoogendoorn echter bedoelt, is de toepassing van andere regels in de geconsolideerde jaarrekening dan uit het dwingendrechtelijk stelsel van de wet voortvloeit.

Dat de toepassing van de bijzondere voorschriften tot het vereiste inzicht leidt, is hèt uitgangspunt van de Vierde EEG-richtlijn. Niet juist is de opmerking dat de eis van het getrouwe beeld een zelfstandige bedrijfseconomische betekenis heeft, 'omdat anders de mogelijkheid van derogatie niet zou zijn opgenomen.' De eis van een getrouw beeld is de doelbepaling die tevens de gedragsnorm bij de toepassing van de bijzondere voorschriften is. Slechts in een uitzonderingsgeval is het in de richtlijn denkbaar dat desondanks geen getrouw beeld wordt gegeven.

Een uitzonderingsgeval kan alleen in bijzondere omstandigheden aan de orde zijn. Dit is ook het systeem van de Nederlandse wet (beperkende werking van de maatstaven van redelijkheid en billijkheid: beperkende werking van de eis van een getrouw beeld). Daaraan doet niet af dat in art. 2:362 lid 4, tweede volzin BW niet over "uitzonderingsgevallen' wordt gesproken. De woordkeuze 'indien noodzakelijk voor het inzicht' is reeds toereikend. Bedacht moet hierbij worden dat het om het totale inzicht gaat.

Hoogendoorn spreekt over 'regelgeving'. Regelgeving is er alleen bij of krachtens de wet. Bij de uitleg ervan kan de jurisprudentie van belang zijn. Particulieren hebben geen bevoegdheidregels voor de jaarrekening uit te vaardigen. Tot die particulieren behoort ook de RJ. Niets belet de RJ om aanbevelingen te geven over een zijns inziens adequate uitleg van bepalingen die niet eenduidig zijn.

Als Hoogendoorn over regelgeving spreekt. doelt hij op de Richtlijnen van de RJ. De RJ zou 
algemene regels hebben uitgevaardigd waarbij een beroep 'kan of moet' worden gedaan op de derogatiebepalingen. Vermoedelijk wordt bedoeld dat de RJ voorbeelden heeft genoemd waarbij in de regel van de 'derogatiebepaling' gebruik 'kan of moet' worden gemaakt. Daar de derogatiebepaling spreekt over 'indien noodzakelijk', $k$ an het alleen om 'moet' gaan. De RJ zou daarom alleen concrete gevallen kunnen noemen die nopen tot afwijking dan wel de RJ noemt factoren die derogatie zouden kunnen indiceren.

De regels van de RJ zouden volgens Hoogendoorn volledig in lijn liggen met de opvatting van de wetgever, onder verwijzing naar opmerkingen in de $\mathrm{MvT}^{5}$ over tussentijdse winstneming bij onderhanden werk. Deze MvT wijst erop dat men in bepaalde bedrijfstakken ziet dat onder bepaalde omstandigheden winst in de vervaardigingsprijs wordt opgenomen voor zover hierdoor een betere voorstelling van het jaarresultaat wordt gegeven. Onder bepaalde omstandigheden voor zover een betere voorstelling van het jaarresultaat wordt gegeven, zijn de door de wetsvoorsteller gegeven clausuleringen. Daarmee heeft de wetsvoorsteller geen algemene grondslag van waardering en resultaatbepaling gegeven, maar alleen een voorbeeld van een geval waarin een individuele rechtspersoon mogelijkerwijze een beroep op de derogatiebepaling kan doen.

Voor wat betreft de hoekmansbedrijven die Hoogendoorn noemt, volsta ik met de opmerking dat het de RJ vrij staat te noemen dat het zijns inziens bij dit type bedrijf noodzakelijk is vlottende effecten tegen beurskoers te waarderen, maar daarbij blijft behoren de toevoeging: 'indien noodzakelijk voor het door middel van de jaarrekening van een hoekmansbedrijf te geven inzicht'. Het gaat daarbij steeds om het totaalbeeld dat de jaarrekening moet geven. De RJ zou ook kunnen schrijven dat hij van oordeel is dat alleen bij deze grondslag dit totaalinzicht wordt gegeven. Dit heeft echter niets te maken met derogatie op het niveau van regelgeving.

Anders dan Hoogendoorn meen ik dat de RJ het niet kan maken te bepalen dat beursgenoteerde effecten tegen marktwaarde moeten worden gewaardeerd. Dit is een oproep tot het handelen in strijd met bepalingen van dwingend recht. De derogatiebepaling helpt hierbij niet. Als namelijk een dergelijk algemene regel zou hebben te gelden, behoort dit in de waarderingsvoorschrif- ten van Titel 9 te staan. In Titel 9 geldt de dwingendrechtelijke regel: verkrijgingsprijs of marktwaarde indien lager, met opgaaf van de beurswaarde in de toelichting. Een derogatiebepaling kan een dergelijke hoofdregel alleen in bijzondere gevallen opzij zetten. Als de RJ een regel formuleert die inhoudt dat altijd van de hoofdregel moet worden afgeweken, is geen sprake van een interpretatie van art. 2:362 lid 4, tweede volzin $\mathrm{BW}$; er is sprake van een oproep tot ongeoorloofde wetsafwijking.

De jaarrekening vormt één geheel. Indien een rechtspersoon de wettelijke regels goed toepast, is sprake van een behoorlijke jaarrekening. Daartoe draagt informatie in de toelichting bij. Als vlottende effecten tegen verkrijgingsprijs zijn gewaardeerd onder opgaaf van de hogere beurswaarde in de toelichting wordt correct gehandeld conform regels van dwingend recht. Deze toelichting vormt geen correctie op de balans en de winst- en verliesrekening maar is dienstig voor het inzicht dat door middel van de jaarrekening moet worden gegeven.

Het is heel goed mogelijk dat voor een bijzondere bedrijfstak het noodzakelijk is de vlottende effecten tegen beurswaarde in de balans te waarderen. Het gaat om een bijzondere situatie. Daarmee is nog niet gezegd dat een meerwaarde dan ook in de winst- en verliesrekening zou moeten worden opgenomen. Een dergelijke handelwijze is in strijd met het realisatiebeginsel. Afwijking ervan is in uitzonderingsgevallen mogelijk (vgl. art. 31 lid 2 Vierde EEG-richtlijn). Het is in de Nederlandse wet zo dat bij de keuze van de grondslag reeds afgeweken kan worden. Het bijzondere voorschrift van art. 2:384 lid 1 BW geeft bij de keuze als leidraad de gedragsnorm van art. 2:362 leden 1-4 aan.

Derogatie "als absoluut vereiste" leidt tot misbruik. Iedereen weet wel iets bijzonders te verzinnen. Ik zie niets in een regel die verbiedt stelsels toe te passen die de RJ niet toestaat. De $\mathrm{RJ}$ is geen instantie die stelsels kan verbreden. Ook is de RJ niet een instantie die afwijkingen van regels van dwingend recht tot wet kan verklaren. Afwijking is de uitzondering, en niet de regel.

Derogatie "als absoluut vereiste" saboteert het harmonisatiestreven. De EEG-richtlijnen kennen diverse opties die als gelijkwaardig worden 
beschouwd; daaraan nog meer opties toevoegen door middel van frequente derogatie maakt het harmonisatiestreven tot een illusie. Hoogendoom acht derogatie ook gewenst om aan te sluiten bij IASC. Ik ben bang dat Hoogendoorn hier de hiërarchie in normen omdraait. Een internationale club van accountantsorganisaties mag best regels uitvaardigen maar dient het recht van de diverse landen te respecteren. Het IASC zou een goede brugfunctie kunnen vormen teneinde de regels van Amerika en de EU (en andere gemeenschappen) nader tot elkaar te brengen. Het gevolg zou kunnen zijn dat Amerikaanse regels en EEGrichtlijnen worden aangepast.

\section{Toepassing van derogatie}

De bepaling omtrent derogatie kan hooguit de waardering (incl. resultaatbepaling) betreffen. Het incident staat hierbij voorop. Het incident kan dan betrekking hebben op bijzondere bedrijfstakken of op de bijzondere situatie waarin een onderneming verkeert. In al deze gevallen moet voorop staan dat afwijking van de wet voor het totaalinzicht noodzakelijk is.

Realisatie vindt plaats na een verkoopovereenkomst gevolgd door aflevering, m.a.w. economische beschikkingsmacht met bijbehorende risico's zijn bij een ander gekomen ${ }^{6}$. Gefaseerde oplevering van deelprojecten van een groter geheel valt daarbinnen ( $v$ an een in aanbouw zijnd flatgebouw is de verdieping op de begane grond na gereedkomen ervan verkocht en overgedragen), maar niet een fase die geen zelfstandig object is (bijv. de liftschacht van een in aanbouw zijnd gebouw). Zou men toch winst nemen dan handelt men in strijd met het realisatiebeginsel. In bijzondere bedrijfstakken zou hierover anders gedacht kunnen worden. Een anders handelen eist dan een specifieke wetsbepaling of beroep op de derogatiebepaling. In dezelfde zin geldt dit voor het verantwoorden van ongerealiseerde waardestijgingen (geen winst!) als winst.

Het achterwege laten van afschrijvingen op slijtend actief is verboden. Hiervan mag niet worden afgeweken. Wel zou het kunnen zijn dat een bepaalde waarderingsgrondslag de toepassing van afschrijving uitsluit. Dit is het geval bij waardering tegen marktwaarde. Deze grondslag is geoorloofd voor beleggingsmaatschappijen. De grondslag marktwaarde geldt echter niet als hoofdregel en komt daarom normaliter voor onroerend goed bij handelsondernemingen en industriële ondernemingen niet aan de orde. Zou onroerend goed niet slijten, dan komt afschrijving niet aan de orde. Dat onroerend goed niet slijt, is echter onjuist. Derogatie komt in deze gevallen niet aan de orde.

\section{Derogatie in andere $\mathbf{E U}$-landen}

Zoals Hoogendoorn heeft opgemerkt, komt derogatie in de meeste landen wel op een of andere wijze voor. In diverse landen is hierbij voor wat betreft het realisatiebeginsel specifiek in de wet een afwijking voor winstneming bij onderhanden werk opgenomen of door verwijzing, in de wet naar 'accounting standards'. Winstneming op afgeronde deelprojecten is ook in Duitsland mogelijk. Derogatie via buitenwettelijke normen zonder grondslag in de wet of jurisprudentie is bij mijn weten in geen enkel EU-land toegestaan, ook niet in Nederland. Iets anders is of in de praktijk niet vaak anders wordt gehandeld. Ik heb geen reden aan te nemen dat daarin Nederland een unieke plaats inneemt. Wel is het zo dat daar waar er een duidelijke fiscale belemmering bestaat. die afwijkingen minder zullen voorkomen. Fiscaal zal er veelal geen bezwaar zijn om ongerealiseerde winst of waardestijgingen in de winst- en verliesrekening op te nemen. Dit leidt tot belastingheffing; om die reden wordt winstneming vermeden. Dit geldt in die landen niet voor een geconsolideerde jaarrekening omdat deze niet maatgevend is voor de belastingheffing.

\section{Afsluitende conclusie}

De eis van een getrouw beeld is een rechtsnorm. De bijzondere voorschriften, met inbegrip van de daarin opgenomen verwijzingen naar een getrouw beeld als gedragsnorm, constitueren een getrouw beeld. Alleen als desondanks geen getrouw beeld wordt bereikt, is afwijking geboden. Het gaat om de uitzondering hetzij door de bijzondere bedrijfstak hetzij door de bijzondere situatie waarin een rechtspersoon verkeert.

Derogatie op het niveau van regelgeving is onbestaanbaar, omdat dan een algemene norm wordt gecreëerd. Algemene normen staan in de regelgeving zelf, zodat niet over derogatie kan worden gesproken. Derogatie op het niveau van quasiregelgeving (zoals RJ) is geen derogatie, 
omdat afwijkingen van dwingend recht niet als algemene regel buiten de wet om dan wel zonder grondslag in de wet met rechtskracht kunnen worden uitgevaardigd.

Het zou kunnen zijn dat bepaalde regels van dwingend recht generiek of voor bijzondere bedrijfstakken naar huidige maatstaven als te streng worden beoordeeld. De geëigende weg is dan wetswijziging. Daarbij dient tevens aandacht te worden besteed aan uitdelingsverboden voor bedragen die als winst worden gepresenteerd zonder dat zij gerealiseerd zijn.

\section{N O T E N}

1 Zie MAB 1995/11, blz. 671.

$2 \mathrm{lk}$ laat banken en verzekeraars buiten beschouwing, gelet op de voor hen geldende afzonderlijke richtlijnen.

$3 \mathrm{lk}$ hanteer deze formulering als equivalent van art. 2:362 lid 1, eerste volzin BW.

4 Voor een doorwrochte beschouwing omtrent de verhouding tussen de algemene bepalingen en de bijzondere voorschriften van onze jaarrekeningtitel verwijs ik voorts naar het in dit blad verschenen artikel van C.A. Boukema (februari/maart 1984, blz. 48-60).

5 Wetsvoorstel 16326, MvT, nr 3, 8 september 1980, blz. 21.

6 Zie H. Beckman, MAB, 1988, blz. 325-341.

\title{
Nawoord bij reacties Beckman en Damen
}

\author{
Prof. Dr. M.N. Hoogendoorn
}

\section{Inleiding}

Op mijn artikel over derogatie in de jaarrekening zijn twee uitgebreide reacties ontvangen, een van Beckman en een van Damen. De reacties zijn zo omvangrijk dat ik mij in mijn nawoord beperk tot de hoofdpunten. Daarbij ga ik in het geheel niet in op de beschouwingen over artikel 2:362 lid 4 BW eerste volzin.

\section{Algemeen}

Op grond van de reacties van Beckman en Damen concludeer ik dat wij een verschillende beschouwingswijze hebben van het derogatievraagstuk en dat wij derhalve artikel 2:362 lid 4 BW tweede volzin verschillend interpreteren. De beschouwingswijze van Beckman en Damen sluit aan op de officiële interpretatie van de EU, zoals

Prof. Dr. M.N. Hoogendoorn is directeur bij Moret Ernst \& Young Accountants, hoogleraar Externe Verslaggeving Universiteit van Amsterdam, onderzoeker Limperg Instituut en medewerker gebruikersdelegatie Raad voor de Jaarverslaggeving weergegeven door Van Hulle (1993). Ik vind het vooral een legalistische beschouwingswijze. Daartegenover stel ik mijn meer bedrijfseconomische beschouwingswijze, die vooral gericht is op de doelmatige oordeels- en besluitvorming van gebruikers van een jaarrekening.

Het verschil in beschouwingswijze blijkt vooral uit vier aspecten:

1 de inhoud die aan het getrouw beeld ofwel aan het inzichtsvereiste wordt gegeven;

2 het verschil tussen de vennootschappelijke en geconsolideerde jaarrekening;

3 het belang dat wordt gehecht aan de Richtlijnen van de Raad voor de Jaarverslaggeving;

4 de vraag of derogatie op het niveau van de regelgeving mogelijk wordt geacht.

\section{Inhoud inzichtsvereiste}

Met betrekking tot het eerste aspect is de gedachte van Beckman dat het voldoen aan de specifieke wettelijke bepalingen in het algemeen leidt tot een getrouw beeld, met als 'sluitstukbepaling' dat daartoe zonodig aanvullende gegevens dienen te worden verstrekt (artikel 362 lid 4 eerste 